Uşak Üniversitesi Sosyal Bilimler Dergisi

$2015,8 / 3$

\title{
Ömer Bedrettin Uşaklı'nın Tüm Şiirlerinin Temalandırılması ve Şiir Dünyasının Hikâyeleştirilmesi
}

Necmi AYTAN*

Ferhat MURAT**

\begin{abstract}
Öz
Bu çalışmanın amacı, bir Anadolu şairi olan Ömer Bedrettin Uşaklı'nın şiirlerinin, tema tema incelenerek yorumlanması ve bu yorumlardan hareketle şiir dünyasının hikâyeleştirilmesidir. Araştırma, nitel araştırma yöntemlerinden doküman analizi ve tematik analiz tekniği ile analiz edilmiştir. Bu çalışmada şairin, Yayla Dumanı, Sarıkız Mermerleri, Deniz Sarhoşları ve kitaplarına almadığı şiirleri incelenmiştir. Bu analizler sonucunda, kendisiyle ilgili 21, tabiatla ilgili 15, sevgi teması çerçevesinde yazılan 29 , siyasi temalı 2 , sosyal temalı 22 , yer ve mekân ile ilgili 9, son olarak da ölüm temasıyla ilgili 13 şiir tematik olarak incelenmiş ve hikâyeleştirilmiştir.

Anahtar Kelimeler: Ömer Bedrettin Uşaklı, Şiir, Tema, Hikâyeleştirme.
\end{abstract}

\section{Themed All Poems of Ömer Bedrettin Uşaklı and the Naration of World Poetry}

\section{Abstract}

The purpose of this study is to review and interpret an Anatolian poet, Omer Bedrettin Uşaklı's poems as theme and from these interpretetions to narrate the world of poetry. In the study qualitative research methods of document analysis and thematic analysis technique was used. In this study the poet's some of the poems as Upland Smoke, Blonde Girl Marbles, Marine drunk and some of the poems which were not included into the poetry were examined. As a result of this analysis, 21 poems concerned with itself 15 about nature, 29 within the framework of love theme, 2 political themed, 22 socialthemed, 9 related to space and location, and finally 13 poems on the theme of death were examined thematically and narrated.

Key Words: Ömer Bedrettin Uşaklı, Poetry, Theme, Narration.

\footnotetext{
* Öğr. Gör. Dr., Süleyman Demirel Üniversitesi, Eğitim Fakültesi, Türkçe Eğitimi Bölümü, necmiaytan@sdu.edu.tr

** Anadolu Üniversitesi, Türk Dili ve Edebiyatı, ferhat_murat_88@hotmail.com
} 


\section{Giriş}

Türk edebiyatında şiir, on dokuzuncu yüzyılın ortalarına kadar kaynağını doğu kültüründen almış ve din eksenli bir beslenmeyle Cumhuriyet döneminin ortalarına kadar devam etmiştir (Parlatır, 1992). Türk şiiri, edebiyat tarihçileri tarafından genel olarak bazı özellikleri dikkate alınarak belli başlı tasniflere ayrılmıştır.

Çalışkan (2010)'a göre, Türk dili ve edebiyatının tarihî süreci, Türk milletinin tarih sahnesinde görüldüğ̈̈ günlere kadar uzanmaktadır. Türk edebiyatı, Türk tarihindeki içtimâî, siyasî ve dinî pek çok kültürel kaynaktan etkilenmiş, gerek nazım ve gerekse nesir türlerinde sayısız eserler veren şahsiyetler ortaya çıkmıştır. Bu şahsiyetlerden biri olan Ömer Bedrettin Uşaklı, cumhuriyetin ilk yıllarında yazdığı şiirleriyle dikkat çekmiştir.

Ömer Bedrettin Uşaklı'nın sanat anlayışının temeli babasını görev yaptığı Uşak ilinde, yani şairin doğduğu yerde (Doğumu; 24 Ağustos 1904Ölümü; 24 Şubat 1946) oluşmaya başlamıştır. Babasının işi gereği Anadolu'nun birçok yerini görme imkânı bulmuştur. Çeşitli Anadolu mekteplerinde tahsilini tamamlayan şairin, küçük yaşlardan itibaren edebiyata karşı bir hevesi oluşmuştur. Şiir ve roman okumaya, yazılar yazmaya çocukluk yıllarından başlamıştır. Yunan istilasından sonra iş gereği gittikleri Sivas'ta edebiyat hocası Kozan Oğlu Cenap Muhittin'in vesilesiyle şairde oluşmaya başlayan edebiyat merakı iyice kuvvetlenmiştir. Bu merak onun Yahya Kemal ve Ahmet Haşim gibi sanatçıları tanımasına ve onlardan etkilenmesine vesile olmuştur. Bu sanatçıların yanı sıra Abdülhak Hamit Tarhan, Namık Kemal, Tevfik Fikret ve Muallim Naci gibi şahsiyetlerin sanat anlayışlarını da kendine yakın bulmuş ve onlardan da özümsediklerini şiirlerine yansıtmıştır (Yazar, 1938).

Enginün (1988)'e göre, Ömer Bedrettin Uşaklı “Gökbelen” soyadını kullanmış, “Uşaklı” soyadını daha sonra almıştır. İlk şiirlerini Servet-i Fünun ve Fecr-i Ati sanatçıları gibi imajlara dayandırarak yazmıştır. Şair adını "Deniz Sarhoşları"yla (1926) duyursa da asıl ününü "Yayla Dumanı" (19341945) ve "Sarıkız Mermerleri" (1940) adlı şiir kitaplarıyla kazanmıştır. Ömer Bedrettin kendi yaşadığ $\breve{l}_{1}$ devirdeki birçok sanatçı gibi Yahya Kemal ve Ahmet Haşim'in tesirinde kalmıştır. İşi gereği Anadolu'yu dolaşması, şairin gezip gördüğü yerleri bir tablo gibi anlatmasına imkân vermiştir. Şiirlerinde halk edebiyatı geleneğinden yararlanmış ve memleket insanını şiirlerinin en önemli temalarından biri haline getirmiştir. Şiirlerinde fazla derine inmeden memleket insanını bir baştan bir başa anlatmıştır. Edebiyatı öze dönmeye aracı kılmaya çalışmıştır. 
Ömer Bedrettin Uşaklı, özellikle Cumhuriyet'ten sonra, "Siyasi ve içtimai, bütün fikir sistemimizle nasıl özümüze doğru yönelmiş bulunuyorsak, edebiyatımızda da elbet bu yönelişin ifadesi olacaktır. Kuvayı milliye, milli mücadele terkipleri hayatta niçin ve hangi ihtiyaçtan doğmuşsa milli edebiyat terkibinin milli kelimesi de sanatta ayn ihtiyaçtan doğmuş ve ruh istiklaline kavuşmanın remzi olmuştur." der. (Enginün, 2001: 181) Bu sebeple Ömer Bedrettin, bugünkü neslin yaratacağı eserlerin, "artık garbın ve şarkın taklidi değil, bizim öz edebiyatımız" olacağını, en kuvvetli en milli eserlerin Yahya Kemal'in çağırdığ taraftan, memleketin içinden Türk'ün ruhundan" doğabileceğini söyler (Enginün 2001: 155; Kılıç, 2005).

Ömer Bedrettin Uşaklı'nın şiirlerinin tematik haritasına bakıldığında Aktaş'a (2008) göre, bu temaları Anadolu insanı ve Anadolu coğrafyası oluşturmaktadır. Yaşanılan mekân olarak daha çok şairin bakış açısında; Anadolu şehirleri, kasabaları ve köyleri önemli bir yer tutmaktadır (Demir, 2013). Anadolu, şairde özellikle de Uşak, ailesinin bulunduğu yerler ve tütünle uğraşan insanlar bulunmaktadır.

Bunların yanında Enginün'e (1988) göre, şairin tütün tahmin memuru görevinden sonra vilayet memuru olarak Bursa'ya tayin edilmesi, daha sonra Türkçe hocalığı yapması ve Tirilye nahiyesinde yaklaşık üç ay kadar nahiye müdür vekilliği yapması, ardından da Mudanya'da kaymakam vekilliği ve asil olarak da Antalya Manavgat'ta kaymakamlık yapması, onun Anadolu insanını tanıması açısından önemlidir. Daha sonraları Ünye, Şavşat, Artvin, Edremit gibi yerlerde görevler yapması şiirlerinin Anadolu'laşmasında önemli paya sahiptir (Demir, 2013).

Şair şiirle ilgili düşüncelerini anlatırken Anadolu’yla yoğrulmuş şiiiri; "Bizim toprağımızdan yoğrulmuş, bizim ateşimizde pişmiş, belki biraz çiy, belki biraz çatlak bir testiden sunulan bizim suyumuz; bizim aradığımız ve susadığımız su..." diye ifade etmiştir (Enginün, 1988). Sanat adamını tarif ederken ise "Allahın kendisine bahşettiği bu özelliğini toplum içinde ne yaptığını bilen ve şuurlu eserler ortaya koyan insan" diye ifade etmiştir. Şaire göre sanat ise tek bir gaye için değil, güzelin ve iyinin hedeflenmesi gereken bir uğraştır (Uşakl1, 1944).

$\mathrm{Bu}$ çalışmada özellikle, Ömer Bedrettin Uşaklı'nın şiirlerinin üzerinden şiire, insana, kendisine ve Anadolu'ya bakışının hikâyeleştirerek verilmesi, sanat ürünlerinin yorumlanması, şiirlerinin geneline bakıldığında şairin sanat dünyasının yansıtılması açısından onun anlaşılmasına ışık tutacaktır. 


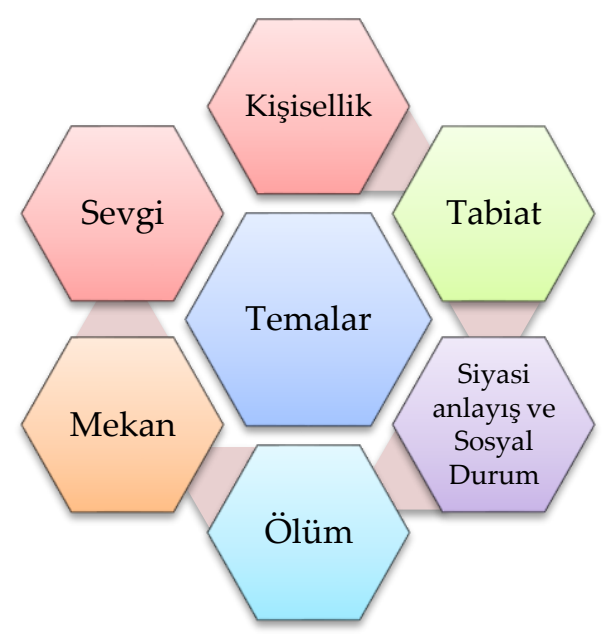

Şekil 1. Şairin Sanatsal Temaları

Şairin şiirle ilgili mülakatları, yazıları ve yüz on bir şiirinin içeriği, onun; kendisi, sevgisi, tabiata bakışı, yer ve mekânla bütünleşmesi, sosyal yaşantının yansıtılması ve yaşanılan bu zamanın bir son bulduğunu ifade ettiği ölümün şiirlerinde tema olarak işlenmesi, şairin genel sanat dünyasını yansitmaktadır.

\section{1. Çalışmanın Amacı}

$\mathrm{Bu}$ çalışmanın amacı, Ömer Bedrettin Uşaklı'nın şiirlerinin, tema tema incelenerek yorumlanması ve bu yorumlardan hareketle şiir dünyasının hikâyeleştirilmesidir

\section{Yöntem}

Çalışmanın bu bölümünde çalışmanın modeli, evren ve örneklem, veri toplama süreci ve veri analizi ele alınmıştır.

\section{1. Çalıșmanın Modeli}

Çalışma, nitel araştırma yöntemlerinden doküman analizi ve tematik analiz tekniği yöntemiyle modellenmiştir. Veriler tematik analiz tekniği ile analiz edilmiştir. Tematik analiz tekniğinde veriler öncelikle kodlanmakta sonra temalandırılmaktadır (Liamputtong, 2009). Bu şiirlerin hikâyeleştirme sürecinde şiirler tema olarak tek tek fişlenerek incelenmiş ve kronolojik olarak hikâye bütünlügü sağlanmaya çalışılmıştır. Hikâyeleştirme sürecinde, analiz sonucu ortaya çıkan her temadan yararlanılmıştır. 


\section{2. Çalışmanın Evreni ve Örneklemi}

Çalışmanın evrenini Ömer Bedrettin Uşaklı'nın şiirleri ve sanat hayatı oluşturmakta, örneklem ise şairin; Yayla Dumanı, Sarıkız Mermerleri, Deniz Sarhoşları ve kitaplarına almadığı şiirlerden oluşmaktadır.

\subsection{Veri Toplama Süreci}

Çalışma kapsamında yaklaşık yüz on bir şiir ve şairin diğer yazıları doküman analizi yöntemiyle incelenmiştir. Tüm şiirleri tek tek okunmuş ve yorumlanmıştır. Yapılan yorumlar ayrı fişlere yazılarak künyeleri belirtilmiştir. Daha sonra da temalandırma işlemi gerçekleştirilmiştir. Bu çalışmalar alanında uzman 2 akademisyene sunulmuş ve temaların hikâyeleştirilmesi işlemi tamamlanmıştır.

\subsection{Verilerin Analizi}

Çalışma kapsamında şairin hayatı ve yaşadığı devir, şiirleriyle ilgili incelemelerden hareketle yorumlanan bütün şiirler, şiirlerdeki mısralara bağlı kalınarak şairin ağzıyla hikâye haline dönüştürülmüştür. Yayla Dumanı, Sarıkız Mermerleri, Deniz Sarhoşları ve kitaplarına almadığı şiirler bu hikâyeleştirmenin temelini oluşturmaktadır. $\mathrm{Bu}$ analizler sonucunda, kendisiyle ilgili 21 şiir, tabiatla ilgili 15 şiir, sevgi teması çerçevesinde yazılan 29 şiir, siyasi temalı 2, sosyal temalı 22 şiir, yer ve mekân ile ilgili 9, son olarak da ölüm temasıyla ilgili 13 şiir tematik olarak yedi aşamada bulgularda sunulmuştur.

\section{Bulgular ve Yorum}

\section{1 Şairin Kendisine Yönelik Tematik Bulguların Hikâyeleştirilmesi}

Şairin kendisini anlattığı 21 şiirde, sevgiliye ve memleketine olan özlem ile denize olan tutkusu ele alındığı anlaşılmaktadır.

Ömrüm boyunca yirmi bir yıl geçmiş ve memleketimin hasretini çekiyorum. Benim yerim bura değil, bahar değil ve başım ise bana yar değgil (DS, Ömrüm). Gurbetteyim ve bu acıyı çekmek zor. Gözlerim yaşlı ve etrafımda postacıyı arıyorum bana memleketimden haber getirecek diye. Akşam olmuş, ufuklar sisli, yollar issiz ve sadece özlemim dolaşıyor sokaklarda (DS, Mektup Beklerken). Bulutların ördüğ̈̈̈, ufukların gördüğ̈̈ mavileşen dağlarda özlemler dağılıyor. Kanadı parçalanmış yorgun martı gibi ah deniz diyerek şen dağlara uçuyorum (SM, Deniz Garibi). Benim denizimde her şey ölçülüdür. Rüzgâr, martı vb... Benim denizimde neler olmaz ki... Onda yaşayan ve onda olan can bulur. Sakindir, sessizdir. Saz benizli periler de vardir (KG, Denizimde). Ben denizle baş başayım. Denizin sessizliğini dinliyorum. Bu 
sessizlik bambaşkadır. Çünkü kenardaki uçurumlar da öyledir. Güneşle beraber çimen, zeytin, defne bunlarm hepsi parlar. Ben her sabah uyandığımda ruhumun sesini ve bülbülün sesini uçurum kenarında dinlerim. Rüzgâr bile inler burada. Burası köyümün en yüksek yeridir (YD, Denizle Baş Başa). Kalbim hayal ve hatıralarla yüklüdür. Deniz ve ben, hayal ve hakikat iç içe girmiş bir manzara. Kalbim bir denizde, bir gurbette atmaktadır. Hummalı gözlerle denizden çıan endamlı güzele bakıyorum. Nağmeli bir ses duyarım. Kum gibi dağılan benim o zaman. Mevsim gibi perişan olan da benim. Ama deniz karşımda ve ruhumdadır (KG, Hayal ve Hatıra). Akşam'ın sessizliği ve deniz durgunluğu gözlerimi yakar sanki. Koydan bir alev topu içime doğru kayar ve halkalanır. Uzaklardaki ateş benim derdime ortaktır. Akşamüstü güneş ise solan bir gül gibiydi (YD, Denizde Akşam). Bir yanda da sevgilimin hayali ve bir yandan da gecenin bunlara şahit olması durmaktadır. Içim öyle yanıyor ki kalp ă̆rımı bir dă̆ dizinde uyutsam ve içime, yangınıma donduran tipiler versem geçmez. Aşağılara şöyle bir baksam ve kışın, beyaz kuşların kirpiklerimde donduğunu görsem. Uyutsam uyutsam bir dă̆ dizinde onları (KG, Karlı Bir Dağ Dizinde). Gölgem sen benimle bütünleşmişsin. Üstünden her şey geçer senin. Seni gören kar, yolunu da değiştirir. Gece sahillerden, yollardan uzanarak gelsen selvi boylum. Bazen ise kolumdasin, bazen ise bir yoldaşsın bana. Sen bela misın? Benim başıma neden sevdiğime benden önce sarllirsin (DS, Gölgem). Ta uzak enginlerden kopup sürüklenerek, kudurarak, mor dalgalar bir biri ardinca gelir. Bu dalgalar evimi kemiriyorlar, beni de götürmek için penceremden giriyorlar (SM, Dalgalar ve Evim). Güzeller bahçesinde kahkahalar, titrek hatıralar, inleyen rüzgâr hepsi var. Kuru ağaçta, taşta, heykelde sanki gizli bir dert bunlar. Havuzun kenarında, incir yapraklarıyla gölgeli bir yerde yılanlar güneşleniyor. Bu bahçede ağaçlar yemyeşil, binlerce narin dilber, tenleri şelale gibidir. Ağaçlar gizlemişler havuza, gölgeleri düşmesin diye. Hem bunlar sonbahar olmadan çürümezler.

Çiçek, kuş, havuza bakan bahçıvan ve yıkanan güzeller şimdi yok hiç biri. Havuz sanki bir mezar gibi, çürümüs yapraklarla birlikte. Bu bahçede baliklar bile yılanlara yem olmuş (SM, Güzeller Bahçesinin Hatırası). Yillarca senin için yazacă̆̆ı şiirimde senin gözlerinin rengini, kirpiklerinin ve yüreğinin güzelliklerini yazmak için sana kavuşacağım bu anı bekliyorum. Bir çağlayan, kışları bahar olan, korkunç bir uçurumun kenarında, şelale diyarında gözlerim ta uzakta senin yolunu gözlüyorum, sana yazacağım şïirimi kaleme almak için. Bir sürü kuş mevsimleri unutmuş, gün ışı̆̆ııı, yanan portakalları, baharı, çiçek açan dalları, yakın uzak ne varsa hepsini unutarak bekledim (SM, Gözlerin Şiiri).

Uçurum kenarındaki nehrin denize bağlanan kısımlarında batakliklar vardır. Buradaki sazliklar adayı andırı. Bu sazlıklar ve kamışların arasından karşımıza uçsuz bucaksız deniz çıkar. İçimizden sular fışkırıyor ve bir yolcu sulara dalıyor. Köylü kızının birisi de bataklı̆̆ın içinde güneşle beraber. Yalnızlı̆̆ımla ve atımla bu geniş ovayı bırakıp kızıl denize gelmekteyim (YD, Bataklık Güneşleri). 
Bomboş bir uçurum kenarının başındayım ve sana hasretim. Arkamda ise sarayın camlari...

Akşamları bu dağlara içimi dökerim. Çünkü burada kendimi daha iyi anlıyorum. Karanlık çöker ve ayın karanlık yüzü görünür. Sudan kurbağalar çıkar. Onlara "siz de benim gibi ağlayın siz de bir gün benim gibi yalnız bırakılacaksınız." derim. Sarayın havuzundan sıtmalı köy damları görünür. (SM, Sarayda Akşam). Nerde o güzel günler. Dalgalarda sallanan bir gemide garip martılar gibi nasıl kavuşmuştuk. Her şeyi unutup saadet ufuklarına doğru uçmuştuk. Her yer sevimliydi. Kalplerimiz ay ışığında ne tatlı gülümsüyordu. Yukarıya çıktıkça şelale, portakal bahçeleri nasıl küçülüyordu. Ah nerde o yüzümüze köpük saçan deniz, nerde şarkılar söylenen o gemiler, bu yolculuğu seneler geçse de silemez. Bir hatıra olarak kalacaktır (YD, Bir Hatıra).

Odamda yatarken şelale sesini ve serinliğini hissediyorum. Onun serinliği yüzüme vuruyor. Duvarlarn serinliğini hissediyorum. Horozlara yalvarıyorum ötmeyin diye. Şelalenin sükûtuyla konuşmak istiyorum. Şelalenin sularında köpükler, portakal, limon ă̆açlarının dalları var. Uykum şelale girdaplarn gibidir. Gündüzde parlayan ışıklar bir köpük gibi. Uykuya kanmak için bunlar yeterli (YD, Uykum). Ben üzgün ve yaralıyım gönülden. Ne yıldız ne şelale ne dağ ne de güneş bensiz, ben de onlarsiz olamam. Onlar bana hayat verir. Bu kaplanın kafesi kırllır o zaman. Limon bahçelerinden esen büyülü rüzgârlar beni diriltsin (YD, Yaralı Kaplan). Ağlayan dertli gönül senin sesinden her şey bıktı artık yeter. Dert namina her şey sende saklanmış. Sen yine de bu gönül hevesinden vazgeç (DS, Gönül).

Etrafımı seyrederken bulutların içinden aşağıya bakıyor her şeyi hissediyor, hatırlıyorum. Her yanı çiçek ve meyve olan bu manzarada güneş sanki bir parmaklıktır. Gözler ufukta, uçup gitmek isteyip de gidememiş gibi ayă̆ında zincir vardır. Tuttuğu yerler sanki ateştendir. Göğsüne değen bu yerler bir elmas gibidir. Kollar ise demirlerde titrer. Her yan gül dolsa da gönül yine de parçalanır. Demirleri hançer gibidir. Ruhuma batar. Gitmek ve güllere karışmak isterim (SM, Şehir Balkonu). Memleketimde bugün harman, ekinler işlenecek. İleride düven süren kızın gözlerinde akşamın gölgesini görüyorum. O kızı insanlığa bahtiyarlık veren bir yar olarak görüyorum. Ona şöyle; adıma "bir kara yazılı" derler diyorum. Ama o bana bahtına değil gönlüne güven diyor (YD, Düven Sürene).

\section{2. Şairin Tabiat ve Doğaya Yönelik Tematik Bulguların}

\section{Hikâyeleştirilmesi}

Tabiatla alakalı yazdığı 15 şiirde daha çok kış mevsimi betimlenmekte ve doğadaki güzelliklerin şairin dünyasında hayal ile gerçek sarmalında kendisinde etkili bir iz bıraktığı anlaşılmaktadır. Tabiat temasında şair; pınar, dağ, çam, söğüt, rüzgâr, çoban, yayla, akan sular ve çağlayan nehirler, duman 
ve sis, şelale, mavi gök ve deniz, martı, yelken, sandal vb. gibi temalara yer vermiştir.

Pınarlar buz tutmuş neşesiz hepsi. Dudaklarda türküler donmuş, süslü dağlarda kuşlar bile yok. Akşam buz olmuş çamlar beyaz giymiş ses bekliyor pınardan. Sular, ağlayan rüzgârla karlara gömülü. Buzunuzu güneş çözecek. Çobanlar ise akın diyecek size. Hiç kimse gelmez kurtlardan başka buraya. Sular mermer gibi donmuş, yolcular pınar sularına hasrettir (SM, Kış Pınarları). Kış her tarafta kendini hissettiriyor. Kar yağınca tepe ve düzlerde çığlar oluşmuş, ufukta güneş bile gözükmüyor. Çam ağaçlarında ise kardan çiçekler var. Eğer bu karlar kürenmezse damları bile çökertecek. İmkânların olmayışından dolayı kızakları bile öküzler çekiyor $(Y D, K \iota s ̧)$.

Ben eriyen kar suyunu içtim. Yaylaların çiçeğini gördüm. Yayla dumanı bu dağların hatırası, akıp giden gümüşüdür. Her şey bu dumanın içinde kaybolur. Yayla dumanı, yemyeşil dağların hem yası, hem de gülüusüdür. Rüzgârın önünden gider ve akan suları gizler. Tabiatın hülyası düşüdür o. Sevgilim neredesin? Rüyada mı, canımda mı? Hayal de olsan gel. Çünkü insanı üşütür bu yayla dumanı (SM, Dağların Düşü). Yayla dumanı her yere dağılır. Karlı dağlar, yeşil çam ormanı, sarı çiçekler, sürüler, yer ve gök her tarafı kontrol ederler. Keşke ben de yayla dumanı gibi olsam ve göklerden her tarafa gidebilsem ve güzelin saçına, başına dolansam. Bunların içinde kaybolsam (YD, Yayla Dumani). Gözlerimle ufuklara bakıp yağız bir tayla dolaşsam. Sese hasretim, insanlara hasretim ben burada. Üstümde ise mavi gök var, nasıl anlatayım. Elimde kamçı, kayaların arasından nal sesleriyle yemyeşil ovalardayım.

Dağ başında, ovada, yokuşta köylerden öğrendiğim bir türkü var. Saçlarımda rüzgâr namesi serin akşamlar dolaşır. Bir dilber eteğinden aldığım üzümleri kaynaklarda soğuturdum. Bazen içim daralırd. Bir nine var beni oğluna benzetirdi. Harmanlarda ise kağnılar gıcırdardı. Ak sıvalı odalarda köylülerin dertlerini ve sevdaların dinlerim. Güneşin parıltısı çamların dallarında görünür. Murat Dağı'nda türküler çobanların kavallarına karışır. Gönlüm o günleri arıyor şimdi. İcimde dağlarm hasreti o âlemleri özlüyorum (SM, Bir Seyahat Hatırası).

Hasretli yolculara buz gibi çağlayan sulara geçit vermem diyen dağın içinden ona, işkence ederek bir tünel açıldı ve tünel, kartal sesini bülbül gibi dinleyen doğa tu..... tu..... diyerek geçti gitti (YD, Tünel). Irmaklar, gözümde yaşlı ve gönlüm taştı bugün. Ben hep sizi düşündüm. Çamları yıkarak denize koşan ırmak size nasıl kıyıyor acaba dă̆ çiçekleri (DS, Dă̆ Çilekleri). Çağlayan sen ki âşıkları dinlersin ama sen de gür sesinle ağlar koynunda kayaları inletirsin. Kızlar, âşıklar senin başına gelir saçları ăgarana kadar. Artık senin başında kimse yok ama senin maceran bana yakın (DS, Çağlayan). Ben de sizin gibi mavi denize akmak ve gülmek istiyorum. Benim gönlümün kasvetinden tek siz anlarsınız. Beni eşime kavuşturacakta sizsiniz. Doğan güneşlerle nasıl parlyyorsanız ben de altın gibi parlıyorum, ebedi sevincinden yaşaran 
gözlerime köpükleriniz sıçrasın. Martı uçuşan ve beyaz yelkenli dolaşan sahillerde beraber gülelim. Çă̆layanlar bir kardeş gibi alın beni aranıza, işleyin ruhumdaki baharı gemi ışıklarıyla süslü hatıralarınıza (SM, Çağlayanlar).

Güneş ışıklarını ırmağın üstüne vurmuş. Nehrin sularında sanki bir ışık akışı var. Söğütlerin arasında ise üç yelkenli var. Direklerinde bayraklar var. İçeriden kaptanların gür sesi geliyor. Akşamın yavaş yavaş çöktüğ̈̈ bu nehirde yapraklar bir bir düşmekte (YD, Irmakta Akşam). Ey şiirler pırlantası güneş, hep başka yerlere git oralarda parla. Beni rahatsı etme. Git başka başka yerlerde parla. Akşamlarda, camlarda, çiçeklerde, mesut olan babaların pembe yüzünde, ölülerin yüzünde, şen çocukların yüzünde parla artık (KG, Doğan Güneşe). Akşam olacak ve biraz sonra yıldızlar çıkacak.

Kızlar çalışma telaşındalar. Pirinç tarlalarının kızıllığı ufuktaki kızıllı̆̆ın yansıması gibidir. Garip bir koku var sanki sıtmayı andıran. Akşam olup iş bitince kızların ağzında bir türkü sanki dönüş türküsü bu (YD, Akşam). Deniz sarhoşları, şarap gibi ufka taparak hep beraber, omuz omuza coşarak, yelken, sandal ne varsa çarpıp geçiyorlar. Başları dik ve gururlu, akşam rengi gibi yanık başları ile sahile koşuyorlar. Bu sarhoşların en yakın arkadaşı rüzgârın ıslı̆̆ıdır. Suların yıllarca yiyip oyduğu bu taşları parçalayıp yiyecekler. Yosunlu kayaların yeşil gözlerini deli âşıklar gibi oyarlar. Bunların gönüllerinde aşkın kini vardır. Bu yaptıklarım bu kinle yaparlar (YD, Deniz Sarhoşları). Direklere insan özellikleri verilmiş. Etrafinda ne varsa sesini duyar, dertlerini anlar. Bu direklerin sanki gizli dertleri varmış gibidir. Direklerin dibini aç kurtlar oyarlar. Bunlar kestirmeden giden yolcular gibi gurbete giderler. Yolcuya yol gösterirler. Selam verirler (YD, Telgraf Direkleri).

Baktı̆̆ım her şeyden bir kırıntı getirip aniden geçti rüzgâr. Dă̆dan, denizden geldi. Iç̧imdeki rengarenk kuşları uçurdu. Ceylanca bir bakış, siyah saçlar gibi geçti, gitti. Es rüzgârım es. Esmemezlik etme sakın. Es ki nehirler uçurumlar ürpersin. Ömrümün ateş harmanı savrulsun (YD, Harman). Gür sesiyle, billur köpükleriyle yată̆ından uçuruma dökülüyor ırmak. Irmak her yere korku salmış ve her şey ondan çekiniyor. Bu harap yerde her yer girdapl ve denize hasretlik var. Çağlayanın sesinden hiç bir şey duyulmuyor. Ama sevincinden gürlemiyor o. Her yerde bu ses duyuluyor. Bu ses gür değil bir ahenk gibi ama suların yası saklı olan bir ses bu (SM, Çağlayan).

\section{3. Şairin Sevgiye Yönelik Tematik Bulguların Hikâyeleştirilmesi}

Şair, sevgi teması çerçevesinde yazdığı 29 şiirde ise bir oba kızını sevmesi, karşılıksız sevgi karşısında yaşamış olduğu iç dünyasındaki feryatlar, sıkıntılar, üzüntü, hasret ve çaresizlik ve bulunduğu yerden uzaklara kaçma, başka yerlerde huzur arama temalarını betimlemiştir.

Obanın kızı Zeynep güzeldir. Alımlı çalımlı ve herkesi etkileyen bir güzelliği vardır. Fakat o nişanlıdır. Çadırında bekleyen bir yiğidi vardır. O yayla çiçeği gibidir. 
Endamı güzelliğiyle, boyuyla huyuyla kendinden âla çiçek olmadığını söyler (DS, Obanın Kızı). Fidan boylum gel gitme. Seller, karlar var zaten. Yokluğun da yakıyor beni. Gözyaşımı sen dindirmezsen el mi dindirecek fidan boylum. Gel gitme, ellerim boynunda kalsin ve geceme yıldiz ol fidan boylum (DS, Fidan Boyluma).

Ben gençliğimi senin yoluna verdiğim halde senden bir vefa görmedim. Gönlüm harap ve içimde kinden bir firtına var artık. Her şeyinle beni bitirdin. Ben o zalim yüreğini parçalasam hiç tasam falan kalmayacak (DS, Aşkımın Kini). Sen hiç dikensiz gül bahçesi gördün mü? Senin ise yüzün benli ama göğsün benli değil. Ben seni sevsem bile sen beni sevmezsin. Gözyaşı dökerim ama sen bilmezsin (DS, Neye Bensiz). Gönlüm o aşkın ince rüzgârnna susadı. Gönlümün o gözlerde gözü var. Bakışı bile sızlayan derdime derman, keşke o bakışlar hep benim olsaydı (DS, Bir Tahassür). Bazen elin saçlarımda olur, bazen sevip okşar, neşelenirim. Eller bazen ise hırçınlaşır bir tokat olur. (DS, Eliniz). Sevgilim seninle gün batmadan kaçalım sonbahara. O perişan diyarlara... Buralardan sıkıldı gönlüm artık. Şu kefen suratlı duvarlara düşman oldum (DS, Gün Batmadan). Gönül yoldaşından ayrilır misın? Boynuma çılgin bir neşeyle sarılır misın? Seni erkenden, rüyan bile bitmeden kaldırsam darılır misın? (DS, Sevgiliye Üç Sual). Gönlüm dilsiz bir kuş gibiydi. Cıvıldadı ve uçtu. Bu kuşun kanadı da kırıktı. Sevgilim onu sen mi dile getirdin? (DS, Gönlüm).

Yıldızların altında sevişmek ve sarhoş olmak başkadır. Yansam, ecel gelse ve gözlerim kapansa bile. Ne keder ne yar. Taşlar elmas olur, kadehim tas olur. Öpmek günah değil, bahtım ise siyah değil, çektiğim ise ah değil, yıldızların altında (DS, Yıldızların Altında). Gülfidanı gibi kıvrllır. Yaz güneşinden kopan ince bir tel gibi, oynak dökülüşleri ve bükülüşleri hep nazdır. Ona sarılsam kırılmazmış (DS, Bel). Sevgilim seninle uzaklara gidelim. Enginlere yelken açalım. Utangaçlı̆ı̆ızla birbirimize bakarak hain ve kıskanç bakışlardan uzak olarak açılalım enginlere... Nefes nefese bizi görse bile rüzgâr fark etmez. Akşamlar, yorgun kanatl eşler, solgun güneşler seyreder bizi. Meleğim gözlerinin rengine ve enginlere bakacağım (SM, Engin Şarkısı).

Yar belini dü̆̆̈̈mlemiş, dağlar ise yollarımı düğ̈̈mlemiş. Uzakta köycükler ışıkları yıldız gibi, evler küçük ve tarlalar sarı. Çamların içinde kaynaştık birbirimize. Ben ateşim o ise peri. Seven ve neşeli kalbe geçitler dar mı acaba? Kollarım ve yollarım düğ̈̈mlenmiş benden bahtiyar var mı acaba? (SM, Dağ Başında Bir Gece). Ruhumuzdaki hudutsuz olan bu sırrı sen ve ben biliyoruz. Kelimesiz, sözsüz, korkarak, gizli gizli ve kimseye görünmeden kalp çarpıntımızda yaşıyor. Bahar gelsin güller gülsün, çiçekler omzuna dökülsün. Güzel karşımda süzülmedikten sonra altın saçları yüzüme dökülmedikten sonra neye yarar. Bu sır gözlerde kalsın gönül her an dertli olsun. Aşk, ayağa düşmeden gizli kalsın. Belki bu çobanın aşkı en ilahisi olanıdır (SM, Sır). İçimde senin aşkın, gençlĭ̆im senin. Beni öldürmeye senin baygın bakışların yeter. O hallerin yeter. Her şeyimizle birlikte bize menekşe türbeli bir mezar 
yeter (SM, Sevgili). Bir yayla evinde seni andim ve hayallerime kondurdum seni. Sesin içimden geldi, duman gibi içime girdin. Görünüp kaybolursun yoksa sen yayla güneşi misin? Çam fidan gibi yalnızım ve ruhum bunaldı. Yayla duman gibi gözümde tüttün (SM, Yayla Güneşi). Beni her şeyinle mest et. Kandır ve nazına, işvene, aşkına sevmene inandır beni. Çılgın âşık gibiyim. Nereye gidiyorum bilmiyorum. Naz yapmadan beni sıkmadan kandır (DS, İhanet).

Ölüm gibi, doğum gibi evime sandalın değirerek geçip gitti. Ince sesiyle anlattı. Denize bakıyorum, bir defa güldü bana. Ahu gözleriyle o bir peri (SM, Deniz Kızı). Gözümün gözü var onun gözlerinde. Derdim için, aşk için bir bakış için, gözlerin derdindeyim. Zaten seneler bana huzur vermedi. Siyah perde gibi önümü gerdi. Buna sen son ver (KG, Ona). Ben ancak, sen rüyama girersen mutlu oluyor, neşeleniyor, hastaysam iyi oluyor ve serinliyorum. Bunlarn hepsi, sen rüyama girdiğinde oluyor (DS, Rüyama Girdiğin Gece). Senin her şeyine vurgunum. Sen meleğim, goncam, gülüm, siyah gözlüm, sen kısaca her şeyimsin. Ben sana vurgunum (DS, Vurgunum). Ne olur bekletme hemen gel. Artık dayanacak gücüm kalmadr. Sakın beni aldatma, günleri saydırma, ne olur gel (DS, Bekletme).

Uşak yöresinde halı dokumak meşhurdur. Sevgiye yönelik bazı şiirlerin konusu da halı dokumayla ilgili hikâyelerdir.

Ayşe bir zengin beyin çocuğuna âşık olur. Ama bunu belli etmez. Kızlarla beraber çalısmaktadır. Halların iyi dokunmasına nezaret eden adam (simsar) Hasanın evleneceğini haber verir. Halıları çabuk dokuyun diye kızları sıkıştırmaktadır. Ayşe sevdiği oğlanın evleneceğini duyunca hayatı yıkılır. Kızlar onu teselli etmeye çalışırlar. Ona derler ki: Hiç olmazsa ona ulaşamadın ama dokuduğun halı ona ulaşacak derler (YD, Ayşe'nin Aşkı).

Şair ise sevgiyi bir türlü elde edememenin feryadıyla kara talihine serzenişte bulunmaktadır.

Benim tahtım dağlardır. Çobanlar benim bağrımı dağlar. Bu kara talihim ise gurbette çağlar durur. Akpinar'a giderken yolumda bir peri var. Kuş sesleri, yaban gülleri var. Sonsuz bir diyarda, mezarm ise dağlarda. Gönül vermeye nazlanan sevgili belki mezarımda ağlar artı (SM, Son Dilek). Ay ırmakta solgun, ben, sen üçümüz varız. Yeşil gündüz ve gece bizim için. Bu geceyi bize bırakmak için battı güneş. Sandalla giderken ay ışı̆̆ı ise uzanmış. Her taraf yemyeşil... Sudan bir yolda gidiyoruz. Ruhumuzu da su gibi akıntıya verdik. Küreklerden damlayan elmaslar, sen, ben ve binlerce senelik kale taşları yanından söğ̈̈t, portakal ve nar ă̆açlarımın kenarından geçtik, gittik (YD, Ay Işı̆̆ında).

Dikilmiş subaşına elinde testisi kıpırdamadan bir hülyaya dalmış. Gözü uzaklardaki dumanlı dağlardadır. Başında yaşmağı, duruşu, endamıyla sen ki köy yıldızı (KG, Köy Yıldızı). Güzele haykırıyor. Şirin bir güzeldir o. Gözlerine hayranlık duyuyor. Elinden bir şey içse ona yeter. Ufuklardaki dağlar birbirine yaslanmış. Yıldızlar çıkmış. Dağların kızı, dağ perisi hepsinden başkadır(YD, Bir Dă̆ Perisine). 
Yukarda ay ve simsiyah gecede bir de sen. Nurlu yüzüne vuran ışıkla sen bir başkasın. Düşünceler bakışlarında titrer ve benim tek aşina olduğum sensin. Rüzgâr saçlarım dă̆ıtır, bu mavi denizin yanında, bu mavi gecede Ay ışı̆̆ında sen...(KG, Ay Işı̆̆̆ında Bekleyiş).

Denize çok büyük bir sevgi besliyorum. Denizden ayrıkken onu hatırlıyorum. Limandaki bağlı gemileri özlüyorum. Deniz suyunda yıkanmamış rüzgârı bile sevmiyorum. Dalgalar gözümde tütüyor. Deniz olmayınca ay ışığı beni güldürmüyor. Senin elma ve findık bahçelerinden denize bakacağın günleri hasretle bekliyorum (YD, Deniz Hasreti).

\section{4. Şairin Siyasi Söyleme Yönelik Tematik Bulguların} Hikâyeleştirilmesi

Siyasi temalı şiirlerinde (2 tane) şair, hürriyet ve cumhuriyetin kolay kazanılmadığını anlatmıştır.

Hürriyeti başımıza taç yaptık. Cumhuriyeti ise kalbimize yazdık. Bir avuç erle Sakarya'dan geçtik. Hedef Akdeniz'dir diyen parmağa koştuk. Yıldızlar yol gösteren oldu. Zafer bahçelerinden gülleri koparmaya, aslanlar gibi dağdan dă̆a vatanı kurtarmaya koştuk. Dumlupınar'a yıldırım gibi düsstük süngülerimizle (SM, Akdeniz'e Doğru). Güneş gibi ışığımız sen oldun. Senin büyüklüğü̈nü ne ses ne renk ne mermer ne ufuklar ne de gökler almaz. Ne mutlu Türk olana, ne mutlu Gazi olana. Ne mutlu gözyaşına ne mutlu yüreğinde ve bulunduğu yerde "Gazi"si olan Türk'e...(SM, Ülkü Tanrımıza).

\section{5. Şairin Sosyal Yaşama Yönelik Tematik Bulguların}

\section{Hikâyeleştirilmesi}

Sosyal temalı 22 şiirde ise Ömer Bedrettin Uşaklı, birçok felaketten temizlenen Anadolu'yu, beşikteki çocuktan şehit olan vatan evlatlarına kadar memleket bünyesinde bulunan genci ve ihtiyarlarıyla tüm vatandaşları anlatmış ve onların milli mücadele sonrası vatana sahip çıkmaları gerektiği temalarını işlemiştir. Şaire göre, vatana büyük bir özveriyle sahip çıkılırsa, birlik ve beraberlik sağlanırsa Anadolu'ya bahar geleceğini, kızların ve işçilerin mutlu olacağını, çocukların ise bu huzur ortamında yüzlerinin güleceğini, bayramların da gerçek bir bayram gibi kutlanacağını mısralarında ifade etmiştir.

Yirminci asır felaketlerle doludur. Ölüm, gözyaşı, hak yeme, sefalet ve saadet bir arada. Bunlar sanki boğuşan iki yılan gibidir. Bunlar her ne kadar olsa da zaman makineleşerek bazı zorlukları beraberinde getirse de gelecek Türkün zaferi olacaktır (KG, Yirminci Asra). 
Farklı bir geceydi. Beşikteki çocuklardan, ölen şehitlere, al kana boyananlardan, zalimlere yıkılanlara kadar... Ve bunları öpenler, kucak kucağa sarılanlar vardır. Dağ taş kül olmuştur. Yanginın kızıl rengi bayrağa vurmuş̧tur.

Bunlar ölürken isli kaldırımlardan bir dü̈̆̈̈̈n gibi savaşa katılanlar geçti. Nurlu bir ihtiyar ise cepheden kaçan oğlunu kurşuna dizdiren kumandana ve askerine hoş geldiniz dedi. Bu savaş karışıklığında bu manzarayı gören ihtiyar oğlunun acısı yüreğine saplansa da o, o acıyı unuttu bile çünkü herkes ya bir zafer müjdesi bekliyor ya da Bursa'yı, İzmir'i soruyordu... Komutan oradakileri yüreklendirici nutuklar atarken kimisi bunun heyecanıyla kimisi de manzaranın dehşetiyle kendinden geçiyordu. İçlerinden bir köylü ise ikram için kumandana bir sigara sundu. Sigarayı sunduğunu gören eski çavuşlardan, oğlu öldürülen adam koştu ve evinin ateşinden bir kor aldı ve kumandanın sigarasını yakarak şükran borcunu ödedi (SM, Yangııların Işı̆̆ııda).

Şair bütün bu olumsuzluklardan yine bir limana kaçmak istemektedir. Her şeyin bir gün daha güzel olacağını hayal etmektedir.

Yillara meydan okuyacak bir gemi istiyorum. Sicactk dumani, yillarca parlayacak ışı̆̆ı olan bir gemi istiyorum. Her şeyiyle garip ruhuma dolan, gönlümde şiir olan bir gemi istiyorum. Küf kokan rıhtımlarını, üzerinde yürüdüğüm kıyılar özledim. Bu rihtımda gözlerim yaşarmadan üzerinde ağladım (YD, Yılların Dirilişi). Yakta kurtulalım. Bir şeyleri yakınca hayatın daha güzel olacağını düşünüyordum. Her taraf düz olsun, yansın kül olsun. Belki bu yanmalar güzel şeylere vesile olur. Ruhumuz, gönlümüz bazı şeyleri yakıp temizleyince daha güzelleşir. Kendimize, özümüze, ocağımıza döneriz...(YD, Ocağıma Karşı).

Şair o dönemlerden bahsediyor. İç geçirerek, o zafer dolu dönemlerin kalmadığı ve denizleri titretenlerin artık yok olduğunu söylüyor. O zaferleri kazananların döneminde olmak ve onların gemisine binmek istiyor.

Tarihe isimlerini altın harflerle yazdıran bu büyüklerin zaferleri zamanında etrafindaki herkesi titretirken şimdi denizler mahzun, ıssız kalmış durumda. Boş gemiler ve heyecansız dalgalar var. Yillar geçtiği halde unutulmayan bu şahsiyetlerin heykelini yaparak bir nevi onu yaşatmak yoluna gidiliyor. Barbaros'un heykeli yine denize karşı, o yine denizle beraber (YD, Barbaros Hayrettim). Zindan simsiyah bulutlar gibi beni sıkıyor. Ufukları arıyorum. O sonsuz genişliği, ovaları, denizi, akşamı, sabahı, tabiatla iç içe olmayı arıyorum. Duvarlara çarparak çırpınan bir kuş gibi çırpinıyorum. Ama ufukları göremiyorum. Bir gün ufuk derdine gönlümü vereceğim ve dağları deleceğim, bir kartal gibi göklere yükseleceğim (YD, Ufuk Hasreti).

Şair bu hayallerden sıyrılarak günlük sosyal hayatın hengâmesini anlatmaya başliyor.

Şehir ve köyü birbirine bağlayan pazar yolculuğu köylüler için heyecan dolu bir gün oluyor. Bu tozlu yollardan akşama doğru dönüyorlar. Eşeklere binen mermer 
bacaklı kızların ayakları üzengilerde ve heybelerde şehirlerden alınan hediyeler, şallar basmalar vs... Toza topră̆a aldırmadan güle oynaya dönüyorlar...(YD, Pazar Dönüşü). Baharm geldiğinden habersiz acele bir şekilde tütün üstüne eğilmiş iş yapmakta olan kızlar. Kimi ağadan bir firsat kollamakta, kimi ise yanındakine derdini anlatmakta, kimi tütün yaprağını dizmede iğneye. Yapraklar güneş görüp buruşmasın diye güneşten korumakta emeğini. Çevresinden habersiz işe dalan kızlar ve iş̧̧iler ekmek parasının derdindeler. Ama ne yapsalar da işlenen tütünler duman olacak (SM, Tütün İşçileri).

Kiraz bahçeleri bir başkadır. Insanlar güzellikleri çinilere işlemektedirler. Kızlar işler dalları, yaprakları ve bu mevsim rüzgâr gibi geçer gider. Kiraz zamanı Hisar'da bayram... Ela gözlerde de bayram vardır. Kızların yazmalarn bir tabiat parçası gibi renklidir (YD, Kiraz Bayramları). Akşam olur gurbet kasveti her yeri kaplar. Güneş ufukta, kızıl bir yelken gibi. Dalgalar, bulutlar yanmış gibi. İçimde bir deli rüzgâr, bir baykuş yanar. İçimde gurbet, dağlar yanar. Çobanın kavalı inine koştu ve bu akşam her şey gurbeti anlatıyor bana (DS, Gurbet Akşamı).Yol uzun, karanlık var, elimizde çıralar, yıldızlar bile geceyi görmüyor. Rüzgâra yol veriyoruz, elimizdeki çırayı söndürmeden, Korkarak, dua ederek, lanetleyerek, gülmeden, türkü bile çağırmadan o ormanda hala yürüyoruz. Bunlar olurken uzaktan bir ses duyuyoruz ve ümitlerimiz yeşeriyor. Üç yolcu uzaktan gelen köpek sesine koşuyoruz (SM, Uzaktan Bir Ses).

Yolculuğa doymadan dă̆ başların gezdim. Çam oluklu pınardan su içtim. Hızımla rüzgârı yardım. Gönlüm ise bahara daldı. Atımın ayakları ise papatyalarda kaldı. Kanadımı zümrüt yeşillikler yükseltti, üveyikler ise atımı ürküttüler. Bülbülü dinleye dinleye, meyve yüklü ağaçlar arasından eğilip geçtim, gittim (SM, Yolculuk).

Çoban kızı ben zafer yolcusuyum. Mataramda suyum yok. Bana yol göster de su bulayım. Pınara varayım. Sen suyumu da yaralı hemşerilerime içirdin. Sürüyü ay ışı̆̆ında bırakan bana bir pınar göster (DS, Zafer Yolcusu). Sahilini, güneşini, çağlayanını, gül kokan bağları, şafakları, tarlaları, çardakları çatlamış damları, gözü yaşlı da olsam özlerim. Gönlüm ise ovada sabahı eder. Akşamları ise dağlardadır gönlüm. (SM, Anadolu Hasreti). Gönül, biz aşk mabedinde güller derdik ve dini orada öğrendik. Birçok naz çektik ama hicran sazının telini gerdik. Dă̆̆, denizi aştık. Sevda havasında olduğumuzdan kendimizi göremedik gönül (DS, Nefes).

Tabiatın harikalarını bırakıp güneşle aydan vazgeçip barlara sürüklendim bir kahkaha peşinden. Nehirler gibi taşkındı o. Ben ise şaşarak yürüdüm ardından. Dertli sazımda yanık türkü yok. Yıllarca boğazımdaki hıçkırıklar birer kahkaha oldu. Testiden boşalan bir şarap gibiydi kahkaha. Ruhumu derinden ayıran bir kahkaha çekti beni barlara, bir daha döner miyim acaba? Rüzgârım yok, kulaklarım duymuyor artık. Bu serin yerler bana kaynaklarımı unutturdu. Artık gözlerim akşamları dans eden bacakları görüyor (SM, Bir Kahkaha Peşinde). Arı balından, gül dikeninden ayrılır mı? Gemim sandalından ayrıldı. Ellerimi bıraktın ama son bir defa görün 
çünkü yüzün güneş gibi. Bir gün belki yine doğar bu güneş. Bu tatll gün bir rüzgâr gibi geçti. Sevgilim elveda sana. Bu hasret güç olacak. Emret de bindiğim gemi dursun $\operatorname{artzk}(S M, V e d a)$.

\section{6. Şairin Yere ve Mekâna Yönelik Tematik Bulguların Hikâyeleştirilmesi}

Şair yer ve mekân temalarında (9 tane), kendi memleketi olan Uşak ve çevresine duyduğu hasreti ve özlemi anlatmıştır. Bu yer ve mekânların dışında, Bursa' da Emir Sultan ve Uludağ, Çoruh nehri ve çevresini, Göksu nehri ve Munzur dağlarının kendisinde bıraktığı etkiyi anlatmıştır. Bunun yanında, düşmanın denize döküldüğü Ege Bölgesini ve efeler diyarını ele almıştır.

Bursa'nın üzerine akşam çöktü. Yeşil ovalara kubbelerin gölgesi düştü. Uludağ etekleri al ipek gibi. Emir Sultan bir alev gibi yanıyor. Uzaktan solgun bir ay görünüyor. Son damlayı güneşten içen karşıdaki kulübe bir sarayı andırıyor. Bir sessizlik var. Ne bir nefes ne de bir kanat sesi. Cennet gibi olan buralarn gönlümde seyrettim bu akşam (YD, Bursa'da Akşam). Çoruh nehrinin etrafindaki uçurumlar yüksektir. Genellikle ışık olmaz. Işı̆̆a hasret olan Çoruh nehrinin suyu da kızıl akar. Akşamlarda burada sakin olur. İçinden geçen kayıklarda ve içindekilerde bir telaş vardır. Kayıklar çekilip itilerek sürüklenir. Dağlar korkunç devler gibi suya girer. Çoruh ise uçurumlarda, akşam olunca kaybolur gider (YD, Çoruh Akşamları). Çoruh, bu gurbet elde yandin mi? Sularm neden kizıl, dilinde Bayburtlu Zihni'nin koşması mı var. Ufkun da şafak, denize döktüğ̈̈̈n toprak, bir sarı toprak olaydım selinde. Burada duramam artık, gel çardak gibi gönlümü yık, beni bırak. Yanık gönlümü götür denize. (SM, Çoruh). Göksu nehrinin sularını içen şen olur. Bu nehir çamlık ormanlardan, dağlardan, güneşin doğduğu yerlerden geçiyor. Gönlümdeki hatıralar bu nehrin sularından daha derin. Bu nehir ayn zamanda aşkımın doğduğu diyarlardan geçiyor. Sevgilimle onun üstündeki köprüden geçtiğimi hatırlıyordum (YD, Göksu).

Gönlümde Gök belenin sevgi ve hatırası vardır. Yayladan geçenler, çamlar, iğdeler vardır orda. Ben sevdiğimle gezmiştim buralarda, bu hatıra dolu yerleri unutamam. Gök belen yaylası onun için hatıralarımda izler bırakmıştır (YD, Gök Belen). Munzur Dağları çok haşindir. Uzaklardan heykeli andırır. Elinde hançeriyle bekleyen suratını saklayan biri gibi durur. Şimşekler onu korkutmaz. Bütün bunların arasında o sanki kükremiş kaplan gibidir (YD, Munzur Dağları).

Uşak'ın her tarafı dalga dalga çiçektir. Akşamları ise bir başkadır burada. Âşıklar diyarı olduğunu akşamın şarap renginden anlıyoruz. Uşak'a kavuşunca neşem yerine geliyor. Zaferin kızıl bir yadigârıdır, uşak akşamları...(YD, Uşak İçin). Sılanın toprağına bırak kendini, ona güven yeter. Onun taşı, toprağı her şeyiyle bütünleş. Çünkü ne yaparsan yap onun kucağında yapıyorsun zaten. Senin ondan 
ayrılman imkânsızdır. Çeşmesinden suyunu içersin, gür sesinle türküsünü söylersin. O senin olduğu için sevinç gözyaşlar dökersin. Herkes seni tanımasa, ailen bile tanımasa o seni yine tanır. Artık gün veda ederken tepelerden, düven sürmeden gelen kızlar vardır. Sen de sevin çünkü köyün görünüyor (YD, Sılanın Toprağında).

Şair, kurtuluş savaşında babasını kaybeden bir çocuğa teselli ve umut verir. Annesiyle beraber olmasını ve ataları gibi onunda her şeyiyle vatana hizmet eden biri olması gerektiğini söyler.

Çocuğa der ki: Başak tutan ellerin bir gün bayrak tutsun (YD, Başaklar Arasında). Efem bu bayram senindir. Elbet oynayacaksın. Gök, dağ her şey seninledir. $\mathrm{Ne}$ mutlu sana... Yöresel bir özellik vardır. Efe genelde Ege Bölgesinin temsilidir (YD, Efenin Bayramı). Efe Ayşe'ye düğ̈̈̈n müjdesi veriyor. Ayşe efenin gönlüne kayıveriyor, efe de onu seviyor. Bir peri kızı gibi saçlarını yayan Ayşe'ye şanımız ve ünümüz var diyor. Onu sevinmesini istiyor (YD, Efenin Müjdesi).

Ben burada misafirim. Bu akşam bahtımın rüzgârına kapıldım. Yolculuğum ise ufuklara. Yar ise elimden tutmuyor. Oysa ben yarna yolcuyum bu misafir yerde... (YD, Akşam Misafiri). Bir atlıya sesleniyorum. Atlının içi içine sığmıyor. Gözleri ateşli, ruhu kanatl, kanlı bir aşk ateşiyle sarhoş, suların coşkun sesiyle alevleniyor. Atını sürdüğ̈̈ zaman izinden yıldırımlar fişkırıyor. Güzeller vurgunu, hasrete ise eskiden yar olan, ardında ise namı dolaşan bir atlder (YD, Kahraman Bir Atliya). Ellerinde balta, ormana doğru giden bu güzellere tahtacı güzelleri diyoruz. Kırmızı, mor ve yeşil fistanlı, gür siyah saçları omuzlarna dökülmüş, göğüsleri taşkın, semiz katırlarıyla, yapraklara basarak ve türkü çağırarak ilerliyorlar. Bunlar yemyeşil ormanların baş tacı güzelleridir (YD, Tahtacı Güzelleri).

\section{7. Şairin Ölüme Yönelik Tematik Bulguların Hikâyeleştirilmesi}

Bu bölümde şairin, hayatın son demi olan ölüm temalı şiirlerine (13 tane) yer verilmiştir. Şaire göre ölüm, hayatın bitişi, yaşanılanların fânileşmesi, sevdiklerinden ayrılma, aile ve dostlarından uzak kalmadır. Bunun için dertlidir ve gözyaşı dökmektedir. Hiçbir şey onu ölüm karşısında teselli edememekte, o da derdini tabiata haykırmakta ve içini dökmektedir. Giden sevdiklerinin geri gelmeyeceğini bilmekte, özellikle de annesi ve kaybettiği kızı için üzülmektedir. Annesinin ölümünü kabullenememekte ve çocuğunun ölümüyle ilgili de çeşmeyle dertleşmektedir.

Bir resme bakar gibi hayallerin iklimine dalıyorum. Düşümü hayal âleminde canlandirıyor. Dă̆, deniz, ufuk, köy, konak, şehirler, nehirler her şey başkalaşıyor ve uzaklara bakıyorum. Damlar buzdan ışıklar gibi bir şafak ve mavzerim bir kız eli gibi omzumda. Türküler "çakırcayım" diye başlıyor dudaklarda. Sen bakışlarımda kaldın, uzaklaşıp gittin. Bu son şehirde kapandı gözlerin. Ben ise şu an şelalelerin sesindeyim (YD, Son Şehir). 
Babasının ölümüne son derece üzülen şaire, tabiat ve dış âlem hüzün verici gözüküyor. Babasının ölümüyle öksüz kalan şairin içinde bir dert, gözünde ise yaş vardır. Kendi varlığının niçin devam ettiğini bile kendine soruyor. Annesinin kendine söz söyleyip ağladığını gözünün önüne getiriyor. Ona hiç bir şey teselli vermiyor. Annesinin kendine söylediklerini deniz ve dağlara söyleyerek derdini tabiat ile paylaşıyor (YD, Silaya Giderken).

Ben de güneş gibi söndüğüm zaman bana rüzgâr ağlar mı? Başucumda bana kimse yanar mı? Bahar seyreder mi acaba tabutumu yeşil dallar arasından geçerken. Bizi candan seven yolcu gelir mi? Dağlar, türkü sesleri kesildi deyip yoksa çam kokusunu göndermez mi? Güllerim derilir mi? Bağımda üzümler erir mi? Bir yudum su veren bir pinar olur mu? Kim bilir (YD, Kim Bilir).

Bir hastane köşesinde bekleyen şair burada annesinin ölümüyle müthiş bir yalnızlık ve üzüntüye kapılıyor Onunla alakalı şeyler bahsettikten sonra, artık onun geri gelmeyeceğini, kendisinin ise yaşamak mecburiyetinde olduğunu biliyor. Onun öldüğüne inanmak istemiyor. Ama tabutu götürürken bütün dünya onun omzundaymış gibi hissedince, anlıyor ki o gerçekten bir daha dönmeyecek (YD, Annemin Ölümü).

Anneciğim öksüz kaldım, elim böğrümde kaldı. Şafak annesi olanlara güneş getirdi. Ama hastanenin koğuşları insana gözyaşı olur. Sevdiğgim bu yerler sana mezar oldu. Mezar taşların çağlayanlar olsun (SM, Anneme).

Şair çeşmeyle vefat eden kızı hakkında dertleşmektedir. İçini döküyor, derdini, ızdırabını anlatıyor. Kendi halinde, tabiatın ortasındaki bu çeşme şaire çocuğu gibi geliyor. Işıklardan korkan çocuğun, babasına seslenişi gibi derin derin şairin ruhuna sesleniyor. Şair hasta insanlar gibi çeşmenin başında sessizce ağliyor.

Bir bahar bile geçmeden çok kısa yaşadı. Ses ver bana çeşmem. Narin bir çiçekti ama beni bıraktı gitti. Ses veren suyunla onu sen mi yıkadın. Altın saçlarıyla, uzun kirpikleriyle neşe onun yüzünde donup kalmıştı. Öldü demeye dilim varmazken şimdi ă̆ıtlar yakıyorum. Onsuz bahçemdeki çiçekler solsun. Seherde yarım yarım şarkılar söylerdi. Yine o şarkı duyuluyor ama hemen kayboluyor. Yavrum soğuğu, tipiyi, şimşekleri görünce korkardı. Zeytinlerle dolu bu tabiatın arasından yıldırım değmiş yaprak gibi uçup gitti. O erken soldu. Çeşmem, ama zeytinlikler hala yemyeşil (SM, Çeşmemle Baş Başa).

Şair bu şiiri ölen kızı için yazıyor. Denizden dilekte bulunuyor. Onu övüyor. Ormanlarıyla, sahiliyle, tepeleriyle, çiçekleriyle, her şeyiyle onun mükemmel olduğunu söylüyor. Ondan da sarıkızın gözyaşı damlamış bir mermer parçası istiyor. Saray yapıp oturmak için değil, havuzlar, heykeller için değil, destanlar, sevdalar yazmak için değil sadece kızı için istiyor (YD, Sarıkız Mermerleri). Şair bir gün öldüğünde toprağa değil de denize gömülmeyi arzuluyor. Gözleri bir gün denize karışıp gidecek (YD, Bir Gün). 
Şair hayattan sıkılmış, günlerin geçmediğini söylüyor. Aylardır kendi yüzünü bile görmüyor. Ardından türküler yakılacak ölüm istiyor. Kaleden değil, nehirden değil ama yiğitçe bir ölüm istiyor. Kendine mertçe bir hançer saplansa huzurlu olacak. Belki de intihar edip kurtulmayı istiyor ama yapamıyor (YD, Bir Hançer İstiyorum).

Bir ses var kulağımda, bana huzur veren bu sesi dinlemek istiyorum. Bu sesle son nefesimi vermek istiyorum. Her şey sussun, sükût bile sussun. Ben sadece o sesi dinleyeceğim. Son nefeste bile (YD, Ses) Hayat devam ediyor. Kuşlar ötüyor, rüzgârlar esiyor ama her baba sesi bende yankılanıyor. Beşik ve salıncaklar görmek istemiyorum. Benliğim her şeyimle seninle bir olsaydı ve her şey seninle toprak olsaydr. O ses bana baba desin istiyorum. Titreyen ruhum böyle mesut olsun. Sen olmayınca ben de mezar istiyorum. Sensiz buralar çekilmiyor (SM, O Ses). Balta karşısında mezarlık ağaçları taş ve toprakların üstüne devrildiler. Bunlar hiç balta girmemiş ama binlerce ölüye şahit olmuşlardır (KG, Mezarlık Ağaçları). Harap bir mezarlikta akşam oluyor. Gece tüm renklerden ayrllip tek renge bürünüyor. Daha sonra ay çıkıyor. Kasvetli bir ortam ve mezarlıkta akşamın krallığı başlıyor. Ayrllık, hasret ve daha neler. Hepsi karanlikta kaybolup gidiyor ve hayat bitiyor (DS, Harap Bir Mezarlikta).

\section{Sonuçlar}

Şairin tüm şiirlerinin temalandırılması ve şiir dünyasının hikâyeleştirilmesi amacından hareketle yaklaşık yüz on bir şiir incelenmiştir. Bunlar, Yayla Dumanı, Sarıkız Mermerleri, Deniz Sarhoşları ve kitaplarına almadığ ilgili 15 şiir, sevgi teması çerçevesinde yazılan 29 şiir, siyasi temalı 2, sosyal temalı 22 şiir, yer ve mekân ile ilgili 9, son olarak da ölüm temasılya ilgili 13 şiire çalışmada yer verilmiştir. Şairin kendisiyle ilgili temalardan başlanmış ve ölüm temasıyla son bulan bir hikâyeleştirme şairin anlatımıyla sunulmuştur. Bu şiirlerin hikâyeleştirme sürecinde şiirler tema olarak tek tek fişlenerek incelenmiş ve kronolojik olarak hikâye bütünlüğü sağlanmaya çalışılmıştır. Yapılan analizlerde;

1. Ömer Bedrettin Uşaklı, kendisini anlattı̆̆ şiirlerinde, sevgiliye ve memleketine olan özlem ile denize olan tutkusunu ele aldığı,

2. Tabiat ve doğayla ilgili yazdığı şiirlerinde daha çok kış mevsimi betimlenmekte ve doğadaki güzelliklerin şairin dünyasında hayal ile gerçek sarmalında kendisinde etkili bir iz bıraktığı ve tabiat temasında şair; pınar, dağ, çam, söğüt, rüzgâr, çoban, yayla, akan sular ve çağlayan nehirler, duman ve sis, şelale, mavi gök ve deniz, martı, yelken, sandal vb. gibi temalara yer verildiği, 
3. Şair, sevgi temalarında ise bir oba kızını sevmesi, karşılıksız sevgi karşısında yaşamış olduğu iç dünyasındaki feryatlar, sıkıntılar, üzüntü, hasret ve çaresizlik ve bulunduğu yerden uzaklara kaçma, başka yerlerde huzur arama temalarını betimlediği,

4. Ömer Bedrettin Uşaklının siyasi ve sosyal temalı şiirlerine bakıldığında; şairin hürriyeti, cumhuriyeti, bağımsızlığı, Anadolu'yu düşmanlardan temizlemeyi ve bu yolda tüm benliğiyle savaşıp vatan için şehit ya da gazi olan vatanseverlere şiirlerinde yer verdiği sonucuna ulaşılmıştır.

5. Sosyal temalı şiirlerinde ise şair, tüm bu felaketlerden temizlenen Anadolu'yu, beşikteki çocuktan şehit olan vatan evlatlarına kadar memleket bünyesinde bulunan genci ve ihtiyarlarıla tüm vatandaşları anlatmış ve onların milli mücadele sonrası vatana sahip çıkmaları gerektiği temalarını işlemiştir. Şaire göre, vatana büyük bir özveriyle sahip çıkılırsa birlik ve beraberlik sağlanırsa Anadolu'ya bahar geleceğini, ekmek parası derdinde olan kızların ve işçilerin mutlu olacağını, çocukların ise bu huzur ortamında yüzlerinin güleceğini, bayramların da gerçek bir bayram gibi kutlanacağını mısralarında ifade etmiştir.

6. Şair yer ve mekân temalarında, kendi memleketi olan Uşak ve çevresine duyduğu hasreti ve özlemi anlatmıştır. Bu yer ve mekânların dışında, Bursa'da Emir Sultan ve Uludağ, Çoruh nehri ve çevresini, Göksu nehri ve Munzur dağlarının kendisinde bıraktığ1 etkiyi anlatmıştır. Bunun yanında, düşmanın denize döküldügü Ege Bölgesini ve efeler diyarını ele almıştır.

7. Şiirlerinin temalandırılmasından yola çıkılarak hikâyeleştirilen Ömer Bedrettin Uşaklının, son olarak da hayatın son demi olan ölüm temalı şiirlerine yer verilmiştir. Şaire göre ölüm, hayatın bitişi, yaşanılanların fânileşmesi, sevdiklerinden ayrılma, aile ve dostlarından uzak kalmadır. Bunun için dertlidir ve gözyaşı dökmektedir. Hiçbir şey onu ölüm karşısında teselli edememekte, o da derdini tabiata haykırmakta ve içini dökmektedir. Giden sevdiklerinin geri gelmeyeceğini bilmekte, özellikle de annesi ve kaybettiği kızı için üzülmektedir. Annesinin ölümünü kabullenememekte ve çocuğunun ölümüyle ilgili de çeşmeyle dertleşmektedir. Şairin işlediği ölüm temalarının daha çok kızıyla ilgili olduğu anlaşılmıştır. 


\section{Kaynakça}

AKTAŞ, Ş. (2008). Yenileşme dönemi Türk şiiri ve antolojisi-2 (1920-1940), Ankara: Akçă̆ Yayınları.

ÇALIŞKAN, A. (2010). Ana çizgileriyle cumhuriyet devri Türk şiirine teorik bir yaklaşım (1923-1960), Uluslararası Sosyal Araştırmalar Dergisi The Journal of International Social Research Vol: 3/10, Winter.

DEMIR, M. (2013). Ömer Bedrettin Uşaklı Şiirlerinde Anadolu gerçeğine bir bakış. Turkish Studies International Periodical for the Languages, Literature and History of Turkish or Turkic Volume 8/13 Fall 2013, $p$. 775-794, Ankara-Turkey.

ENGINÜNN, İ. (1988). Ömer Bedrettin Uşaklı (Bütün Eserleri). Ankara: Türk Dil Kurumu Yayınları.

ENGINÜNN, İ. (2001). Cumhuriyet Dönemi Türk Edebiyatı. İstanbul: Dergâh Yayınlar.

KILIÇ, A. F. (2005). Sabahattin Eyuboğlu'nun halk kültürü ve sanat eserlerine yaklaşımı. Atatürk Üniversitesi Kazım Karabekir Ĕ̆itim Fakültesi Dergisi, (12), 256.

LIAMPUTTONG, P. (2009). Qualitative data analysis: conceptual and practical considerations. Health Promotion Journal of Australia, 20(2), 133-139.

PARLATIR, İ. (1992). XIX. Yüzyıl Yeni Türk Şiiri. Türk Şiiri Özel Sayısı IV (Çă̆daş Türk Şiiri), Ankara.

UŞAKLI, Ö. B. (1944). Sanatta konu ve milli benlik. Varlı, C. 14, 256-257 (Mart).

YAZAR, M. B. (1938). Edebiyatçılarımız ve Türk Edebiyatı. Ankara: Kanaat Kitapevi. 